\title{
DNA with zwitterionic and negatively charged phosphate modifications: Formation of DNA triplexes, duplexes and cell uptake studies
}

\author{
Yongdong Su${ }^{1}$, Maitsetseg Bayarjargal ${ }^{1}$, Tracy K. Hale ${ }^{1,2}$ and Vyacheslav V. Filichev ${ }^{* 1,2, \S}$
}

\author{
Full Research Paper \\ Address: \\ ${ }^{1}$ School of Fundamental Sciences, Massey University, Private Bag \\ 11-222, 4442 Palmerston North, New Zealand and ${ }^{2}$ Maurice Wilkins \\ Centre for Molecular Biodiscovery, Auckland 1142, New Zealand \\ Email: \\ Vyacheslav V. Filichev ${ }^{*}$ - v.filichev@massey.ac.nz \\ * Corresponding author \\ § Fax: (+) 6463557953 \\ Keywords: \\ cell uptake; charge neutral modification; DNA; modified phosphates; \\ Staudinger reaction
}

Open Access

\author{
Beilstein J. Org. Chem. 2021, 17, 749-761. \\ https://doi.org/10.3762/bjoc.17.65 \\ Received: 08 December 2020 \\ Accepted: 11 March 2021 \\ Published: 29 March 2021 \\ This article is part of the thematic issue "Celebrating the role of chemistry \\ in the success of oligonucleotides as therapeutics". \\ Guest Editors: P. Kumar and T. Brown \\ (C) 2021 Su et al.; licensee Beilstein-Institut. \\ License and terms: see end of document.
}

\begin{abstract}
Two phosphate modifications were introduced into the DNA backbone using the Staudinger reaction between the 3',5'-dinucleoside $\beta$-cyanoethyl phosphite triester formed during DNA synthesis and sulfonyl azides, 4-(azidosulfonyl)- $N, N, N$-trimethylbutan-1aminium iodide ( $\mathrm{N}+$ azide) or $p$-toluenesulfonyl (tosyl or Ts) azide, to provide either a zwitterionic phosphoramidate with $\mathrm{N}+$ modification or a negatively charged phosphoramidate for Ts modification in the DNA sequence. The incorporation of these $\mathrm{N}+$ and Ts modifications led to the formation of thermally stable parallel DNA triplexes, regardless of the number of modifications incorporated into the oligodeoxynucleotides (ONs). For both $\mathrm{N}+$ and Ts-modified ONs, the antiparallel duplexes formed with complementary RNA were more stable than those formed with complementary DNA (except for ONs with modification in the middle of the sequence). Additionally, the incorporation of $\mathrm{N}+$ modifications led to the formation of duplexes with a thermal stability that was less dependent on the ionic strength than native DNA duplexes. The thermodynamic analysis of the melting curves revealed that it is the reduction in unfavourable entropy, despite the decrease in favourable enthalpy, which is responsible for the stabilisation of duplexes with $\mathrm{N}+$ modification. $\mathrm{N}+\mathrm{ONs}$ also demonstrated greater resistance to nuclease digestion by snake venom phosphodiesterase I than the corresponding Ts-ONs. Cell uptake studies showed that Ts-ONs can enter the nucleus of mouse fibroblast NIH3T3 cells without any transfection reagent, whereas, N+ONs remain concentrated in vesicles within the cytoplasm. These results indicate that both $\mathrm{N}+$ and Ts-modified ONs are promising for various in vivo applications.
\end{abstract}

\section{Introduction}

The ability to detect and modify the genome of living organisms is important for the diagnosis, prevention, and treatment of many diseases [1]. The site-specific targeting and manipulation of genomic DNA or RNA using chemically modified short oligodeoxynucleotides (ONs) is considered to be a viable therapeutic strategy [2-5]. Antigene strategies use ONs to specifi- 
cally bind native DNA, induce genomic changes, and/or interfere with gene expression. Apart from strategies that use modular enzymes such as zinc-finger nucleases [6] or transcription activator-like effector nucleases (TALENs) [7] to recognise and cut DNA sequences, or CRISPR-CAS9 [8-10] and CAS9-constructs [11-14] which rely on large proteins to open the target duplex, triplex-forming oligonucleotides (TFOs) [15] can be designed to bind in a sequence-specific manner to double-stranded DNA (dsDNA) [16]. In forming the parallel triple-helix structure, a polypyrimidine TFO binds to dsDNA through Hoogsteen base-pairing [17], in which the cytosine bases in the TFO are protonated at the N3 atom (Figure 1B).

In antisense strategies, antisense ONs (AOs) interact with RNA molecules to interfere with protein expression $[18,19]$. The major challenge in designing chemically modified ONs as antigene/antisense agents is to ensure an efficient cellular uptake and nuclease resistance while still maintaining, or ideally increasing, binding affinity and specificity of the ONs towards their DNA or RNA target.

Many synthetic analogues of natural ONs, such as peptide nucleic acids (PNA) [20], locked nucleic acids [21] (LNA, also known as bridged nucleic acids (BNA) [22]) and phosphorothioate (PS) ONs $[23,24]$ have been evaluated for antigene/anti- sense applications, however, each of the analogues did not meet all the requirements. For example, both PNA and modified PNAs have excellent chemical stability, are resistant to enzymatic degradation, and have high binding affinity towards complementary DNA and RNA, but have a tendency to aggregate, require high salt conditions, and have low solubility in water $[1,25,26]$. LNA (BNA) have an enhanced thermal stability in DNA triplexes and duplexes, a high binding affinity to RNA, and are nuclease resistant [22,26-28]. These properties have led to LNA (BNA) being used in various therapeutic ONs that have reached clinical trials [29]. However, the multistep synthesis of LNA and increased hepatotoxicity of some modified AOs ensure that further optimisation is required [30]. Chemical modification of ONs with a PS linkage resulted in ONs resistant to nuclease degradation but with several side effects due to nonspecific interactions with cellular components [31].

Modifications of the phosphate backbone of DNA and RNA, especially charge neutral modifications, have gained attention in recent years because such modifications not only improve the nuclease resistance of ONs but also enhance their affinity towards complementary DNA/RNA/dsDNA and improve cell uptake. The lack of a negatively charged backbone also improved the binding of PNA to DNA or RNA strands. It has been shown that positively charged PNA bind more strongly to DNA

A)<smiles></smiles>

Q

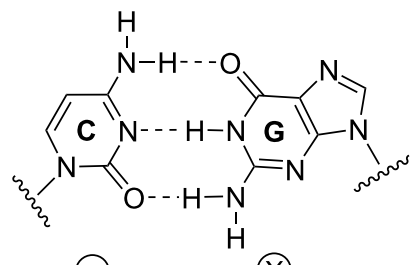

B)

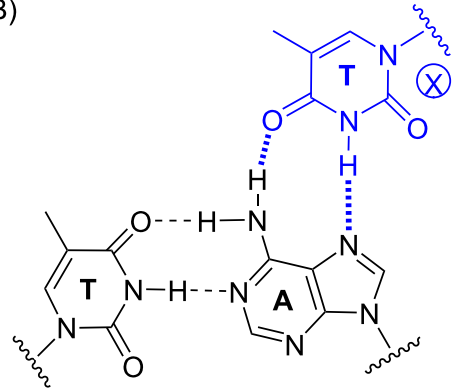

$\odot$ $\otimes$

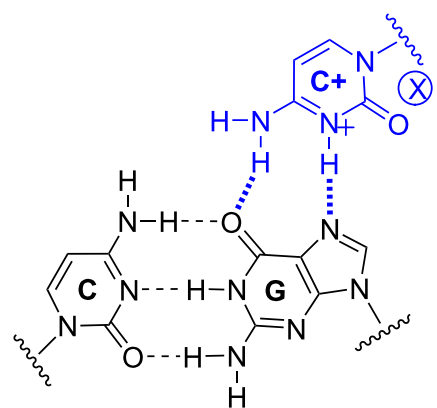

(X)

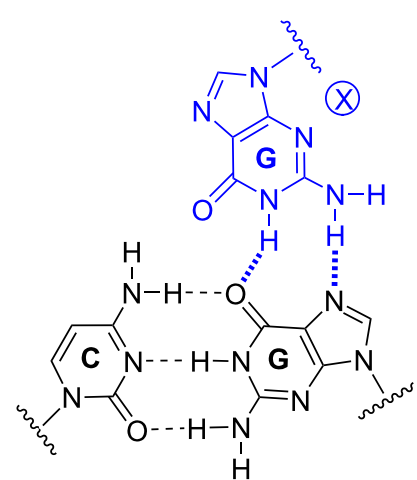

(X)

Figure 1: Illustration of H-bonding in a DNA duplex and a parallel triplex. A) Depiction of Watson-Crick base-paring (left: T-A and right: C-G); B) parallel triple helices: pyrimidine-rich third strand interactions are stabilised by Hoogsteen hydrogen bonds (the duplex is in black, TFO is in blue, Watson-Crick base-paring is shown with dashed bonds, and Hoogsteen base-paring is shown with hashed bonds). The relative orientation of phosphodiester backbones is indicated by the symbols " $\odot$ " and " $\bigotimes$ ". 
and RNA than negatively charged PNA at low salt concentrations $\left(0-100 \mathrm{mM} \mathrm{Na}^{+}\right)$whereas at medium to high salt concentrations $\left(250-1000 \mathrm{mM} \mathrm{Na}^{+}\right)$the trend is reversed [32].

As a charge-neutral phosphate mimic, the methylphosphonate linkage (PMe) has been introduced into the DNA backbone to improve stability of ONs towards enzymic digestion as well as DNA duplex and triplex binding affinity [33]. However, the poor aqueous solubility [34], reduced binding affinity with complementary RNA [35], and a destabilising effect on the thermal stability of G-quadruplexes [36] hinders its application. In contrast, a phosphate methylated linkage (POMe,) marginally destabilised complementary DNA but improved sequence specificity [37].

Recently, we synthesised a G-rich $\mathrm{ON}\left(\mathrm{TG}_{4} \mathrm{~T}\right)$ with all phosphates replaced by a 4-(trimethylammonio)butylsulfonyl phosphoramidate group $(\mathrm{N}+$, Scheme 1$)$. The sequence was designed to obtain the formally charge-neutral zwitterionic $\mathrm{N}+\mathrm{TG}_{4} \mathrm{~T}$ [38]. Each negatively charged phosphoramidate is neutralised by the positively charged quaternary ammonium group, providing a zwitterionic phosphate mimic. The resistance to enzymatic degradation, a higher thermal stability, and a faster association that was independent of ionic strength was observed for this N+-modified G-quadruplex $\left(\mathrm{TG}_{4} \mathrm{~T}\right)_{4}$. These properties encouraged us to evaluate the $\mathrm{N}+$ modification in the context of DNA duplexes and triplexes and to perform celluptake studies. For comparison, we also evaluated the properties of ONs modified with a tosyl sulfonyl phosphoramidate (Ts) that results in a negatively charged phosphate mimic [39].
The introduction of each, $\mathrm{N}+$ or Ts modification creates a chiral center at the phosphorus atom resulting in a mixture of $2^{n}$ diastereomers, where $n$ is the number of modified phosphate groups. The reverse-phase (RP) HPLC purification occasionally results in the separation of individual diastereomers (usually for ONs with a single modification), which supports the insignificant difference in the lipophilicity of the diastereomeric ONs. We hypothesised that, in comparison with native ONs, the N+ONs should hybridise with higher affinity to complementary single-stranded DNA (ssDNA) or RNA due to both a reduced repulsion between negatively charged phosphates and a thermal stability being less dependent on the ionic strength of the solution. Moreover, N+ONs carrying zwitterionic phosphates could lead to an increased cell uptake.

For both $\mathrm{N}+$ and Ts modifications, we synthesised 14-mer ONs with either one, two, three, or four modifications introduced at various positions in the sequence. The thermal stability of a parallel DNA triplex and duplexes of DNA and RNA formed with these ONs where then evaluated. Thermal denaturation experiments, nuclease resistance and cell-uptake assays were also conducted to evaluate these chemically modified ONs.

\section{Results \\ Synthesis and purification of modified ONs}

4-(Azidosulfonyl)- $N, N, N$-trimethylbutan-1-aminium iodide [38] and tosyl azide ( $p$-toluenesulfonyl azide, $\mathrm{TsN}_{3}$ ) [39] were synthesised and used for the synthesis of the modified ONs using an automated DNA synthesiser as described. The solution of sulfonyl azide $\left(0.5 \mathrm{M} \mathrm{TsN}_{3}\right.$ in $\mathrm{MeCN}$ or $0.7 \mathrm{M}$ 4-(azidosulfonyl)- $N, N, N$-trimethylbutan-1-aminium iodide in DMF) was
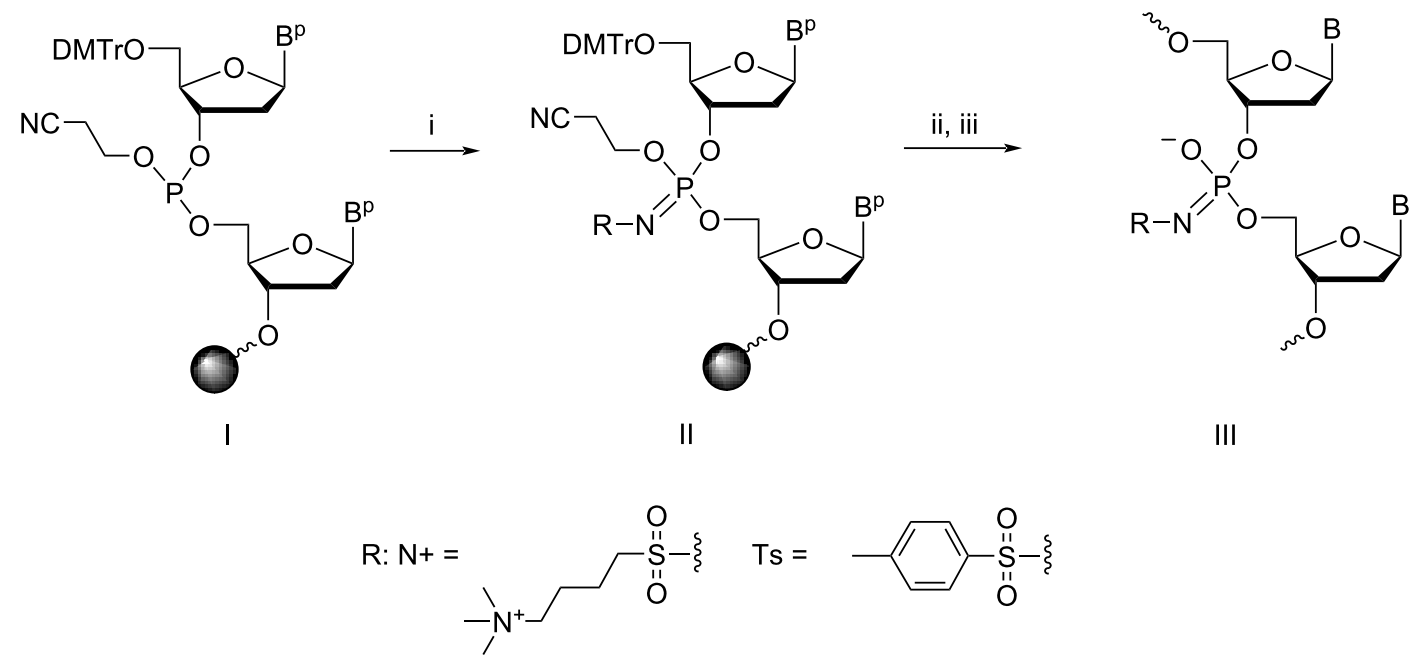

Scheme 1: The synthesis of $\mathrm{ONs}$ with $\mathrm{Ts}$ and $\mathrm{N}+$ modification using the Staudinger reaction during the solid-phase DNA synthesis. Conditions: (i) $0.5 \mathrm{M} \mathrm{TsN}_{3}, \mathrm{MeCN}, 37^{\circ} \mathrm{C}, 30 \mathrm{~min}$ for Ts modification; $0.7 \mathrm{M} \mathrm{4}$-(azidosulfonyl)- $N, N, N$-trimethylbutan-1-aminium iodide, DMF, $37{ }^{\circ} \mathrm{C}, 30$ min for the $\mathrm{N}+$ modification; (ii) DNA synthesis; (iii) conc. aq $\mathrm{NH}_{3}, 55^{\circ} \mathrm{C}, 12 \mathrm{~h}$; $\mathrm{B}$ /B: protected/deprotected heterocyclic base; DMTr: 4,4'-dimethoxytrityl. 
introduced as replacement of a standard iodine/pyridine oxidation step to react with 3 ',5'-dinucleoside $\beta$-cyanoethyl phosphites (Scheme 1, I), forming the $N$-modified iminophosphorane (Scheme 1, II). ONs bearing one or more $N$-modified phosphoramidate groups (Scheme 1, III) were obtained after the removal of the protective groups and $\beta$-cyanoethyl groups using $\approx 28 \%$ ammonia. We found out that a higher conversion was observed when performing the Staudinger reaction at $37{ }^{\circ} \mathrm{C}$ rather than at room temperature. The yield was also improved by minimising the handling of the solid support and performing the reaction using a microtube pump to deliver the sulfonyl azide solution onto the column with CPG support. The cleaved and deprotected $\mathrm{N}+-$ and Ts-ONs were initially purified using reversed-phase (RP) HPLC. However, the separation of ONs with varying numbers of modifications was not ideal as there were only marginal changes in the retention time in RP-HPLC. Therefore, ion-exchange (IE) HPLC was used for purifying these ONs. The substitution of each phosphate with $\mathrm{N}+$ modifi- cation, resulted in a shorter retention time $(\tau)$ in IE-HPLC ( $\Delta \tau=-3 \mathrm{~min} /$ modification, Table 1$)$. For Ts-modified ONs, the incorporation of the Ts modifications, as a result of increased hydrophobicity, led to an increased retention time $(\Delta \tau=+1.5$ to $+2 \mathrm{~min} /$ modification, Table 1) compared to the native sequence. The composition of the ONs was confirmed by electrospray ionization mass spectrometry (ESIMS) in the negative mode (Table 1). For clarity, we introduced the following nomenclature of the ONs synthesised. The prefix 5'- or 3'- with either N+ or Ts- means that the first phosphate at the 5'- or 3'-end was modified; $\mathrm{m}-\mathrm{N}+$ or $\mathrm{m}$-Ts- indicates that the named modification was incorporated in the middle of the sequence; $2 \mathrm{~N}+, 3 \mathrm{~N}+$, $4 \mathrm{~N}+$ or $2 \mathrm{Ts}-$, 3Ts-, 4Ts- indicates that two, three, or four modifications were distributed evenly in the sequence.

The solubility of the ONs was not influenced by the introduction of Ts and $\mathrm{N}+$ modifications, as the purified, desalted, and lyophilised ONs were fully dissolved in $50 \mu \mathrm{L} \mathrm{H}_{2} \mathrm{O}$. The

Table 1: Names of the ONs synthesised, their sequences, retention times on the ion-exchange column ${ }^{\mathrm{a}}$, compositions, and isolated yields.

\begin{tabular}{|c|c|c|c|c|c|}
\hline & sequence & $\begin{array}{l}\text { retention time } \\
(\min )\end{array}$ & calculated MW & observed $\mathrm{MW}^{\mathrm{b}}$ & $\begin{array}{l}\text { isolated yield } \\
(\%)\end{array}$ \\
\hline ON1 & 5'-ССССТTTСТTTTTT' & 31.53 & 4121.7 & - & \\
\hline $5^{\prime}-\mathrm{N}+\mathrm{ON} 2$ & $5^{\prime}-\mathrm{C}_{\mathrm{N}+}$ CCCTTTCTTTTTT & 27.76 & 4296.7958 & $4297.7588^{d}$ & $9^{e}$ \\
\hline m-N+ON3 & 5'-CCCCTTT ${ }_{N_{+}}$CTTTTTT & 27.43 & 4296.7958 & $4297.7455^{d}$ & $11^{e}$ \\
\hline $3^{\prime}-\mathrm{N}+\mathrm{ON} 4$ & 5'-CСССТTTCTTTTT $\mathrm{N}_{+}{ }^{\top}$ & 27.74 & 4296.7958 & $4297.7466^{d}$ & $20^{f}$ \\
\hline 2N+ON5 & 5'- $\mathrm{C}_{\mathrm{N}_{+}} \mathrm{CCCTTTCTTTTT}_{\mathrm{N}_{+}} \mathrm{T}$ & 23.42 & 4473.9012 & $4473.8248^{d}$ & $8^{e}$ \\
\hline $3 N+O N 6$ & $5^{\prime}-\mathrm{C}_{\mathrm{N}_{+}}$CCCTTT $_{\mathrm{N}_{+}}$CTTTTT $_{\mathbf{N}_{+}} \mathrm{T}$ & 20.77 & 4649.0067 & $4650.1412^{d}$ & $10^{e}$ \\
\hline 4N+ON7 & $5^{\prime}-\mathrm{C}_{\mathrm{N}_{+}} \mathrm{CCCT}_{\mathrm{N}_{+}} \mathrm{TTCT}_{\mathrm{N}_{+}}$TTTT $_{\mathrm{N}_{+}} \mathrm{T}$ & 17.09 & 4826.0965 & $4826.0516^{d}$ & $23^{f}$ \\
\hline $4 \mathrm{~N}+\{\mathrm{FAM}\}$ & $5^{\prime}-\mathrm{C}_{\mathrm{N}_{+}} \mathrm{CCCT}_{\mathrm{N}_{+}} \mathrm{TTCT}_{\mathrm{N}_{+}}$TTTT $_{\mathrm{N}_{+}}$T\{FAM $\}$ & $-g$ & 5396.4012 & $5396.1460^{h}$ & 20 \\
\hline 5'-Ts-ON8 & $5^{\prime}-\mathrm{C}_{\mathrm{Ts}} \mathrm{CCCTTTCTTTTTT}$ & 32.80 & 4272.7151 & $4274.6664^{d}$ & $4^{e}$ \\
\hline m-Ts-ON9 & 5'-CCCCTTT ${ }_{\text {Ts }}$ CTTTTTT & 32.75 & 4272.7151 & $4273.4728^{d}$ & $5^{e}$ \\
\hline 3'-Ts-ON10 & 5'-CCССTTTCTTTTT ${ }_{\text {Ts }}{ }^{\top}$ & 32.81 & 4272.7151 & $4273.4694^{h}$ & $8^{e}$ \\
\hline 2Ts-ON11 & $5^{\prime}-\mathrm{C}_{\mathbf{T s}} \mathrm{CCCTTTCTTTTT}_{\mathbf{T s}_{\mathbf{s}}{ }^{T}}$ & 35.67 & 4425.7398 & $4427.7401^{\mathrm{h}}$ & $6^{e}$ \\
\hline 3Ts-ON12 & $5^{\prime}-\mathrm{C}_{\mathrm{Ts}} \mathrm{CCCTTT}_{\mathrm{Ts}} \mathrm{CTTTTT}_{\mathrm{Ts}} \mathrm{T}^{\mathrm{T}}$ & 36.76 & 4578.7646 & $4578.6076^{i}$ & $30^{f}$ \\
\hline 4Ts-ON13 & $5^{\prime}-\mathrm{C}_{\mathrm{Ts}} \mathrm{CCCT}_{\mathrm{Ts}}$ TTCT $_{\mathrm{Ts}}$ TTTT $_{\mathrm{Ts}} \mathrm{T}^{\mathrm{T}}$ & 40.07 & 4731.7893 & $4731.7620^{j}$ & $39^{f}$ \\
\hline 4Ts-\{FAM $\}$ & $5^{\prime}-\mathrm{C}_{\mathbf{T} \mathbf{s}} \mathrm{CCCT}_{\mathbf{T} \mathbf{s}} \mathrm{TTCT}_{\mathbf{T} \mathbf{s}} \mathrm{TTTT}_{\mathbf{T} \mathbf{s}} \mathrm{T}\{\mathrm{FAM}\}$ & $-\mathrm{g}$ & 5301.2398 & $5302.8380^{h}$ & 26 \\
\hline m-N+ON14 & 5'-CCCCTTTCTTT ${ }_{\mathbf{N}+}$ TTT & 27.50 & 4296.7958 & $4296.7520^{d}$ & $19^{f}$ \\
\hline $\mathrm{m}-\mathrm{N}+\mathrm{ON} 15$ & 5'-CCCCTTT $\mathrm{C}_{\mathrm{N}_{+}}$TTTTTT & 27.43 & 4296.7958 & $4296.7300^{d}$ & $16^{f}$ \\
\hline $\mathrm{m}-\mathrm{N}+\mathrm{ON} 16$ & 5'-CCCC $\mathrm{N}_{+}$TTTCTTTTTT & 27.45 & 4296.7958 & $4296.7440^{d}$ & $17^{f}$ \\
\hline $\mathrm{m}-\mathrm{N}+\mathrm{ON} 17$ & 5'-CC ${ }_{N_{+}}$CCTTTCTTTTTT & 27.62 & 4296.7958 & $4296.7350^{d}$ & $21^{f}$ \\
\hline $3 N+O N 18$ & $5^{\prime}-\mathrm{C}_{\mathrm{N}_{+}} \operatorname{CCCTT}_{\mathrm{N}_{+}}$TCTTTTT $_{\mathrm{N}_{+}} \mathrm{T}$ & 20.44 & 4649.0067 & $4649.937^{d}$ & $17^{f}$ \\
\hline
\end{tabular}

a IE-HPLC was performed on an IE-column (TSKgel Super Q-5PW) using a gradient of $\mathrm{NaCl}$ concentration $(0 \rightarrow 0.5 \mathrm{M})$ in $20 \mathrm{mM} \mathrm{Tris-HCl,} 1 \mathrm{mM}$ EDTA, pH 9.0 over $30 \mathrm{~min}$; ${ }^{b}$ based on ESIMS in the negative mode; ${ }^{\mathrm{C}}$ obtained from Integrated DNA Technologies; ${ }^{\mathrm{d}} \mathrm{calculated}$ for $[\mathrm{M}-6 \mathrm{H}]^{6-}$;

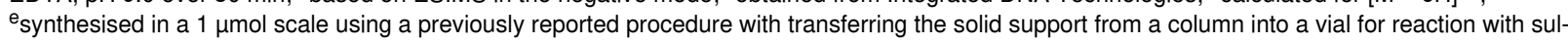
fonyl azide for $30 \mathrm{~min}$ at room temperature. Afterwards, the solid support was transferred back to the column to continue DNA synthesis [39]. Some amount of the solid support was lost during the transfer and washing steps, especially for multiple modifications, which was the main reason for the

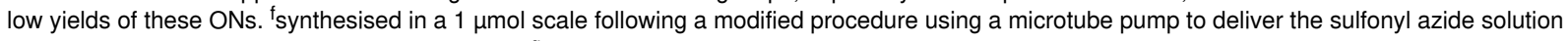
onto the column with CPG-support at $37^{\circ} \mathrm{C}$ [38]; 9synthesised in a 3-4 $\mu$ mol scale, purified by $20 \%$ denaturing PAGE (7 M urea), followed by extraction from the gel and desalting. ${ }^{h_{\text {for }}}[\mathrm{M}-7 \mathrm{H}]^{5-}$; ifor $\left[\mathrm{M}+\mathrm{K}^{+}-9 \mathrm{H}\right]^{8-}$; f for $[\mathrm{M}-4 \mathrm{H}]^{4-}$; the ESIMS spectra are provided in Supporting Information File 1. 
Ts-modified ONs have previously been shown to marginally destabilise duplexes with complementary DNA and RNA [39]. The chemical stability of $\mathbf{5}-\mathbf{N}+\mathbf{O N} \mathbf{2}$ at various $\mathrm{pH}$ (5.5, 7.0, and 8.5) was evaluated by incubation in $10 \mathrm{mM}$ Na phosphate buffer (140 mM NaCl, $0.1 \mathrm{mM} \mathrm{Na}_{2}$-EDTA) at $50{ }^{\circ} \mathrm{C}$ for $24 \mathrm{~h}$. No degradation was observed according to IE-HPLC analysis (see Figure S16 in Supporting Information File 1), which ensures that the N+-modified ONs will be chemically stable during the evaluation of the thermal stability of complexes with complementary DNA and RNA.

\section{Thermal denaturation experiments}

The thermal stability of antiparallel ON/RNA and ON/DNA duplexes as well as parallel DNA triplexes was assessed in thermal denaturation experiments and the results are summarised in Table 2.

The sequences possessing a different number of $\mathrm{N}+$ and $\mathrm{Ts}$ modifications were studied initially in an antiparallel duplex formed with complementary RNA and compared with the corresponding antiparallel DNA duplexes at $\mathrm{pH}$ 7.0. Apart from the ONs possessing modifications in the middle of the sequence (entries 6, 9, and 12 in Table 2), stabilised ON/RNA duplexes were obtained for both $\mathrm{N}+\mathrm{ONs}\left(\Delta T_{\mathrm{m}}=+1-+12{ }^{\circ} \mathrm{C}\right.$, entries 2-7, Table 2) and Ts-ONs $\left(\Delta T_{\mathrm{m}}=+7\right.$ to $+11^{\circ} \mathrm{C}$, entries $8-13$, Table 2). The highest thermal stabilisation against RNA induced by a single modification was observed for ONs with one modification at 3 '-end $\left(\Delta T_{\mathrm{m}}=+12{ }^{\circ} \mathrm{C}\right.$ and $+11{ }^{\circ} \mathrm{C}$ for $\mathrm{N}+$ and Ts modifications, respectively). The corresponding antiparallel DNA duplexes were less thermally stable with $\Delta T_{\mathrm{m}}=-1$ to $+2{ }^{\circ} \mathrm{C}$. The same trend was seen for ONs with a modification at both the 5'- and 3'- ends: ON/RNA duplexes were more stable $\left(\Delta T_{\mathrm{m}}=+7{ }^{\circ} \mathrm{C}\right.$ for $\mathbf{2 N + O N 5}$ and $\Delta T_{\mathrm{m}}=+10^{\circ} \mathrm{C}$ for $\left.2 \mathrm{Ts}-\mathbf{O N 1 1}\right)$ than the corresponding antiparallel DNA duplexes $\left(\Delta T_{\mathrm{m}}=+2{ }^{\circ} \mathrm{C}\right.$ for $2 \mathrm{~N}+\mathbf{O N 5}$ and $\Delta T_{\mathrm{m}}=+1{ }^{\circ} \mathrm{C}$ for 2Ts-ON11). The thermal stability of the ON/RNA duplexes was not improved by increasing the number of $\mathrm{N}+$ or $\mathrm{Ts}$ modifications in the ONs.

Table 2: $T_{\mathrm{m}}\left[{ }^{\circ} \mathrm{C}, \pm 0.5^{\circ} \mathrm{C}\right]$ data for triplex and duplex melting, taken from UV melting curves $(\lambda=260 \mathrm{~nm})$. entry antiparallel duplex triplex ${ }^{c}$

\begin{tabular}{|c|c|c|c|c|c|c|}
\hline & & \multirow{2}{*}{$\begin{array}{l}\text { RNA }^{\mathrm{a}} \\
\mathrm{pH} 7.0\end{array}$} & \multicolumn{2}{|c|}{ DNA $^{b}$} & \multirow{2}{*}{$\mathrm{pH} 5.0^{\mathrm{d}}$} & \multirow{2}{*}{ pH 6.0} \\
\hline & & & pH 5.0 & $\mathrm{pH} 7.0$ & & \\
\hline 1 & ON1 & 46 & 48 & 50 & 45 & 28 \\
\hline 2 & $5^{\prime}-\mathrm{N}+\mathrm{ON} 2$ & $53(+7.0)$ & $44(-4.0)$ & $51(+1.0)$ & $40(-5.0)$ & $25(-3.0)$ \\
\hline 3 & $\mathrm{~m}-\mathrm{N}+\mathrm{ON} 3$ & $47(+1.0)$ & $43(-5.0)$ & $48(-2.0)$ & $55(+10.0)$ & 28 \\
\hline 4 & $3^{\prime}-\mathrm{N}+\mathrm{ON} 4$ & $58(+12.0)$ & $46(-2.0)$ & $52(+2.0)$ & $56(+11.0)$ & $29(+1.0)$ \\
\hline 5 & 2N+ON5 & $53(+7.0)$ & $44(-4.0)$ & $52(+2.0)$ & $56(+11.0)$ & 28 \\
\hline 6 & $3 N+O N 6$ & $41(-5.0)$ & $45(-3.0)$ & $51(+1.0)$ & $48(+3.0)$ & $<15$ \\
\hline 7 & 4N+ON7 & $55(+9.0)$ & $48(0.0)$ & $51(+1.0)$ & $48(+3.0)$ & 28 \\
\hline 8 & 5'-Ts-ON8 & $54(+8.0)$ & $39(-9.0)$ & $46(-4.0)$ & $51(+6.0)$ & $24(-4.0)$ \\
\hline 9 & m-Ts-ON9 & $44(-2.0)$ & $31(-17.0)$ & $37(-13.0)$ & $51(+6.0)$ & $<15$ \\
\hline 10 & 3'-Ts-ON10 & $57(+11.0)$ & $44(-4.0)$ & $49(-1.0)$ & $54(+9.0)$ & $27(-1.0)$ \\
\hline 11 & 2Ts-ON11 & $56(+10.0)$ & $43(-5.0)$ & $51(+1.0)$ & $53(+8.0)$ & $25(-2.0)$ \\
\hline 12 & 3Ts-ON12 & $38(-8.0)$ & $40(-8.0)$ & $45(-5.0)$ & $49(+4.0)$ & $<15$ \\
\hline 13 & 4Ts-ON13 & $53(+7.0)$ & $39(-9.0)$ & $44(-6.0)$ & $47(+2.0)$ & $20(-8.0)$ \\
\hline 14 & $\mathrm{~m}-\mathrm{N}+\mathrm{ON} 14$ & $54(+8.0)$ & - $^{\mathrm{e}}$ & $51(+1.0)$ & - & - \\
\hline 15 & $\mathrm{~m}-\mathrm{N}+\mathrm{ON} 15$ & $56(+10.0)$ & - & $51(+1.0)$ & - & - \\
\hline 16 & m-N+ON16 & $54(+8.0)$ & - & $55(+5.0)$ & - & - \\
\hline 17 & $\mathrm{~m}-\mathrm{N}+\mathrm{ON} 17$ & $56(+10.0)$ & - & $52(+2.0)$ & - & - \\
\hline 18 & $3 N+O N 18$ & $54(+8.0)$ & - & $51(+1.0)$ & - & - \\
\hline
\end{tabular}

The RNA sequence for the antiparallel duplex formation is ON19: $3^{\prime}$-rGGGGAAAGAAAAAA; $c=1.0 \mu \mathrm{M}$ of each strand in 20 mM sodium cacodylate, $100 \mathrm{mM} \mathrm{NaCl}, 10 \mathrm{mM} \mathrm{MgCl}_{2}, \mathrm{pH} 7.0$; the $T_{\mathrm{m}}$ values for the ON/RNA duplexes were confirmed by CD melting experiments (Figures S7 and S8, and

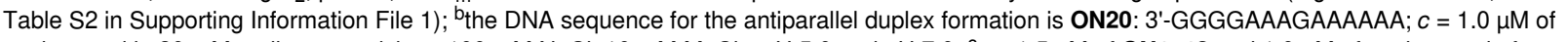
each strand in $20 \mathrm{mM}$ sodium cacodylate, $100 \mathrm{mM} \mathrm{NaCl}, 10 \mathrm{mM} \mathrm{MgCl}_{2}, \mathrm{pH} 5.0$ and $\mathrm{pH} 7.0 ;{ }^{\mathrm{c}} \mathrm{C}=1.5 \mu \mathrm{M}$ of $\mathrm{ON1}-13$ and $1.0 \mu \mathrm{M}$ of each strand of dsDNA (D1: 3'-CTGCCCCTTTCTTTTTT/5'-GACGGGGAAAGAAAAAA) in $20 \mathrm{mM}$ sodium cacodylate, $100 \mathrm{mM} \mathrm{NaCl,} 10 \mathrm{mM} \mathrm{MgCl} 2, \mathrm{pH} 5.0,6.0$ and 7.0; duplex $T_{\mathrm{m}}=56.5^{\circ} \mathrm{C}\left(\mathrm{pH} \mathrm{5.0)}, 58.5^{\circ} \mathrm{C}(\mathrm{pH} 6.0)\right.$, and $57.0^{\circ} \mathrm{C}(\mathrm{pH} 7.0)$; triplex formation was confirmed by size-exclusion HPLC (SE-HPLC) in sodium cacodylate buffer $\left(\mathrm{pH} 5.0\right.$ and $\mathrm{pH}$ 6.0, Figure $\mathrm{S} 15$ in Supporting Information File 1), no triplex was formed at $\mathrm{pH} 7.0$; ${ }^{\mathrm{d}}$ the $T_{\mathrm{m}}$ for triplex melting was determined by subtraction of the duplex melting curve from the overlaid melting curve (Figure S6 in Supporting Information File 1); ${ }^{\text {enot }}$ performed. 
For Watson-Crick-type duplexes, both the $\mathrm{N}+$ and Ts modifications destablised the DNA duplex at $\mathrm{pH}$ 5.0. The destablising effect was more pronounced for $\mathrm{Ts}$ than for the $\mathrm{N}+$ modification $\left(\Delta T_{\mathrm{m}}=-17\right.$ to $-4{ }^{\circ} \mathrm{C}$ for Ts and -5 to $0{ }^{\circ} \mathrm{C}$ for $\mathrm{N}+$ modifications, respectively). For the antiparallel ON/DNA duplexes formed at $\mathrm{pH}$ 7.0, when comparing ONs with the same number of modifications, the $\mathrm{N}+$ modifications led to higher $T_{\mathrm{m}}$ values than Ts-ONs. The incorporation of three and four Ts moieties led to a further decrease in the $T_{\mathrm{m}}$ whereas the corresponding $\mathrm{N}+\mathrm{ONs}$ did not disrupt the duplex thermal stability. These results indicate that the $\mathrm{N}+$ and $\mathrm{Ts}$ modifications can be viewed as RNA-like modifications, because their use in ONs led to higher $\Delta T_{\mathrm{m}}$ values for ON/RNA than for ON/DNA duplexes.

The same modified sequences (ON1-13) were also studied in a pH-dependent Hoogsteen-type base-pairing towards the duplex D1 forming a parallel triplex [40]. As can be seen in Table 2, all parallel triplexes formed at $\mathrm{pH} 5.0$ were more thermally stable than at $\mathrm{pH} 6.0$ and no triplex was formed at $\mathrm{pH} 7.0$, which is consistent with the trend for parallel triplexes based on CT-TFOs [41]. Some fluctuations were observed for Hoogsteen-type triplexes formed by $\mathrm{N}+\mathrm{ONs}$. A modification at the 5' end destabilised triplexes at both pH 5.0 and $6.0\left(\Delta T_{\mathrm{m}}=-5^{\circ} \mathrm{C}\right.$ and $-3{ }^{\circ} \mathrm{C}$, respectively, Table 2 ). All other $\mathrm{N}+\mathrm{ONs}$ formed more stable triplexes with $\mathbf{D 1}$ at $\mathrm{pH}$ 5.0, while marginal changes were observed for triplexes at $\mathrm{pH} 6.0$ except for $\mathbf{3 N + O N 6}$ with three modifications that did not form a triplex. The incorporation of Ts modifications led to stabilised Hoogsteen-type triplexes at $\mathrm{pH} 5.0\left(\Delta T_{\mathrm{m}}=+2\right.$ to $+9{ }^{\circ} \mathrm{C}$, Table 2$)$, whereas triplexes at $\mathrm{pH} 6.0$ were less stable $\left(\Delta T_{\mathrm{m}}=-1\right.$ to $\left.-8{ }^{\circ} \mathrm{C}\right)$. For Ts-ONs with the modification in the center of the sequence (m-Ts-ON9 and 3Ts-ON12), no triplex formation was observed at $\mathrm{pH}$ 6.0/room temperature. These results show that Hoogsteen-type triplexes with single $\mathrm{N}+$ or Ts modifications at the 3'-end are more thermally stable at the 5'-end, and that increasing the number of modifications showed no advantage for $T_{\mathrm{m}}$ of parallel triplexes.

A position-dependent influence of the $\mathrm{N}+$ and Ts moieties on the $T_{\mathrm{m}}$ is suggested by the less thermally stable duplexes formed by the ONs with a single modification in the middle of the sequence (in TC motif) compared to native DNA. We synthesised another set of N+ONs, with single (ON14-17, entries 14-17, Table 2) and triple modifications (ON18, entry 18 , Table 2) that had no modifications in the center of the sequence and evaluated the thermal stability of their antiparallel duplexes formed with complementary RNA and DNA at $\mathrm{pH}$ 7.0. The results in Table 2 show that $\mathbf{O N 1 4 - 1 7}$ form more stable duplexes with RNA $\left(\Delta T_{\mathrm{m}}=+8\right.$ to $\left.+10{ }^{\circ} \mathrm{C}\right)$ and DNA $\left(\Delta T_{\mathrm{m}}=+1\right.$ to $+5{ }^{\circ} \mathrm{C}$ ). It is interesting that sequences with the $\mathrm{N}+$ modifica- tion in the CT motif ( $\mathbf{m}-\mathbf{N}+\mathbf{O N} 15$ and $\mathbf{m}-\mathbf{N}+\mathbf{O N 1 6})$ did not destabilise the antiparallel duplexes unlike the $\mathrm{N}+$ modification in the TC motif ( $\mathbf{m}-\mathbf{N}+\mathbf{O N} \mathbf{3}$ and $\mathbf{3 N + O N 6}$ ). One possible reason for this position-dependent influence of the $\mathrm{N}+$ and $\mathrm{Ts}$ moieties on the duplex stability might be due to a propeller twist [42] in the TC dinucleotide interfering with the $\mathrm{N}+$ and Ts moieties and destabilising the DNA and RNA duplexes.

Next, we evaluated the binding affinity of the $\mathrm{N}+$ and Ts-modified ONs for complementary DNA and RNA at different salt concentrations $(25,50$, and $100 \mathrm{mM} \mathrm{NaCl}$, Table 3$)$. It has been reported that the thermal stability of DNA duplexes decreases as salt concentrations are reduced due to the increased electrostatic repulsion between the negatively charged phosphates [43]. The native DNA duplex ON1/ON20 showed a decline in the $T_{\mathrm{m}}$ values from 50 to $37{ }^{\circ} \mathrm{C}$ and to $19{ }^{\circ} \mathrm{C}$, when the $\mathrm{NaCl}$ concentration was decreased from 100 to $50 \mathrm{mM}$ and to $25 \mathrm{mM}$, respectively (Table 3). A similar trend was observed for the Ts-modified ONs as the backbone is still negatively charged. In contrast, for the N+ONs the decrease in the $T_{\mathrm{m}}$ with decreasing $\mathrm{NaCl}$ concentration was not as significant as for the negatively charged ONs, and the $T_{\mathrm{m}}$ value at a $25 \mathrm{mM}$ salt concentration was $20{ }^{\circ} \mathrm{C}$ higher than the $T_{\mathrm{m}}$ for the unmodified duplex, and $12{ }^{\circ} \mathrm{C}$ higher than the Ts-modified duplex. However, such behaviour was not as noticeable for the duplexes formed with complementary RNA. The $T_{\mathrm{m}}$ value of the control ON/RNA duplex (ON1/ON19) decreased by $2{ }^{\circ} \mathrm{C}$ when the $\mathrm{NaCl}$ concentration was reduced from 100 to $25 \mathrm{mM}$, whereas the $T_{\mathrm{m}}$ for the $\mathrm{N}+\mathrm{ON} / \mathrm{RNA}$ duplex $(\mathbf{4 N}+\mathbf{O N} 7 / \mathbf{O N} 19)$ decreased by $10{ }^{\circ} \mathrm{C}$, although it was still more thermally stable than the control ON/RNA duplex. In contrast, the duplex formed by Ts-ON and RNA (4Ts-ON13/ON19) was destabilised $\left(\Delta T_{\mathrm{m}}=-6{ }^{\circ} \mathrm{C}\right)$ at the lowest salt concentration tested.

We analysed the melting profiles and obtained the thermodynamic parameters of the duplexes at different salt concentrations ignoring the changes in DNA and salt concentrations induced by solution evaporation, the change of $\mathrm{pH}$ during heating, and assuming that there is no change in the heat capacity $\left(\Delta c_{\mathrm{p}}=0\right)$ [45]. We also assumed a two-state transition between duplex and single-stranded DNA and a linear relationship between the CD/UV signal and fraction of molecules unfolded (see Supporting Information File 1 for the analysis of the melting curves). As the thermal stability of DNA duplexes increased with increasing concentrations of salt, we expected a favourable $\Delta H$ of duplex formation at a higher salt concentration. However, in all cases studied, $\Delta H$ was less favourable at $100 \mathrm{mM}$ than at $25 \mathrm{mM} \mathrm{NaCl}$. Recently, similar observations have been reported for DNA modified with methyl phosphotriester linkage (POMe) using isothermal titration calorimetry (ITC) measurements which provides $\Delta H$ values directly [37]. 
Table 3: The $T_{\mathrm{m}}\left[{ }^{\circ} \mathrm{C}\right]$ and thermodynamic data at $298 \mathrm{~K}$ for the antiparallel duplexes at different $\mathrm{NaCl}$ concentrations, taken from UV melting curves $(\lambda=260 \mathrm{~nm})^{\mathrm{a}}$

\begin{tabular}{|c|c|c|c|c|c|c|}
\hline & $\begin{array}{l}\text { antiparallel } \\
\text { duplex }\end{array}$ & $\mathrm{NaCl}(\mathrm{mM})$ & $T_{\mathrm{m}}\left({ }^{\circ} \mathrm{C}\right)^{\mathrm{b}}$ & $\Delta H^{\mathrm{c}}(\mathrm{kJ} / \mathrm{mol})$ & $T \Delta S(\mathrm{~kJ} / \mathrm{mol})$ & $\Delta G_{298}(\mathrm{~kJ} / \mathrm{mol})$ \\
\hline \multirow[t]{9}{*}{ ON/DNA } & ON1/ON20 & 25 & 19 & $-430( \pm 20)$ & $-400( \pm 20)$ & $-30( \pm 28)$ \\
\hline & & 50 & 37 & $-400( \pm 9)$ & $-350( \pm 8)$ & $-50( \pm 12)$ \\
\hline & & 100 & 50 & $-368( \pm 8)$ & $-305( \pm 7)$ & $-63( \pm 10)$ \\
\hline & $4 \mathrm{~N}+\mathrm{ON} 7 / \mathrm{ON} 20$ & 25 & $41(+22.0)$ & $-388( \pm 9)$ & $-334( \pm 8)$ & $-54( \pm 12)$ \\
\hline & & 50 & $44(+7.0)$ & $-322( \pm 15)$ & $-266( \pm 14)$ & $-56( \pm 20)$ \\
\hline & & 100 & $51(+1.0)$ & $-320( \pm 8)$ & $-260( \pm 7)$ & $-60( \pm 10)$ \\
\hline & 4Ts-ON13/ON20 & 25 & $29(+10.0)$ & $-382( \pm 14)$ & $-340( \pm 14)$ & $-42( \pm 19)$ \\
\hline & & 50 & $34(-3.0)$ & $-372( \pm 12)$ & $-326( \pm 11)$ & $-46( \pm 16)$ \\
\hline & & 100 & $45(-5.0)$ & $-354( \pm 7)$ & $-297( \pm 7)$ & $-57( \pm 10)$ \\
\hline \multirow[t]{6}{*}{ ON/RNA } & ON1/ON19 & 25 & 44 & $-390( \pm 10)$ & $-332( \pm 9)$ & $-58( \pm 13)$ \\
\hline & & 100 & 46 & $-306( \pm 17)$ & $-248( \pm 17)$ & $-58( \pm 24)$ \\
\hline & $4 \mathrm{~N}+\mathrm{ON} 7 / \mathrm{ON} 19$ & 25 & $45(+1.0)$ & $-419( \pm 7)$ & $-359( \pm 6)$ & $-60( \pm 9)$ \\
\hline & & 100 & $55(+9.0)$ & $-329( \pm 13)$ & $-264( \pm 12)$ & $-66( \pm 17)$ \\
\hline & 4Ts-ON13/ON19 & 25 & $38(-6.0)$ & $-420( \pm 20)$ & $-370( \pm 20)$ & $-50( \pm 28)$ \\
\hline & & 100 & $53(+7.0)$ & $-407( \pm 13)$ & $-337( \pm 12)$ & $-70( \pm 17)$ \\
\hline
\end{tabular}

aOne $\mu \mathrm{M}$ of each strand in $20 \mathrm{mM}$ sodium cacodylate buffer ( $\mathrm{pH} 7.0$, supplemented with 25,50 , or $100 \mathrm{mM} \mathrm{NaCl}$, respectively); ${ }^{\mathrm{b}} T_{\mathrm{m}}$ values are reported with $\pm 0.5^{\circ} \mathrm{C}$ uncertainties as determined from several experiments; values in parentheses are $\Delta T_{\mathrm{m}}$ values calculated as $T_{\mathrm{m}}$ (sample) - $T_{\mathrm{m}}$ (unmodified duplex) at the same salt concentration; ' ${ }^{C}$ thermodynamic parameters are calculated as described in Supporting Information File 1 (see also Figures S9-S14) at $298 \mathrm{~K}$, errors were calculated as described in reference [44].

For the native DNA duplex (ON1/ON20), the more favourable $\Delta H$ at the low salt concentration $(25 \mathrm{mM} \mathrm{NaCl})$ was deprived by an even higher entropy penalty leading to a loss in $\Delta G$ $\left(\Delta \Delta G_{298}=33 \mathrm{~kJ} / \mathrm{mol}\right)$, thus lowering the $T_{\mathrm{m}}$ value at $25 \mathrm{mM}$ $\mathrm{NaCl}$. For the unmodified RNA duplex (ON1/ON19), $\Delta \Delta H$ between $25 \mathrm{mM}$ and $100 \mathrm{mM} \mathrm{NaCl}$ is $84 \mathrm{~kJ} / \mathrm{mol}$, and the corresponding entopic factor $\Delta(T \Delta S)$ is $84 \mathrm{~kJ} / \mathrm{mol}$. As a result, changes in $\Delta G_{298}$ were negligible as reflected by the small decrease in the $T_{\mathrm{m}}$ value $\left(\Delta T_{\mathrm{m}}=2{ }^{\circ} \mathrm{C}\right)$ when the salt concentration was reduced from $100 \mathrm{mM}$ to $25 \mathrm{mM} \mathrm{NaCl}$.

For the N+ or Ts-modified ONs, $\Delta H$ for ON/DNA duplexes was less favourable at the same salt concentration than for the unmodified duplex, whereas $T \Delta S$ was more favourable. According to Kuo et al. [37], an increase in the salt concentration stabilises the DNA duplex by reducing the entropy costs of duplex formation rather than by reducing the strand charge repulsion. This reduction of entropy costs for duplex formation is due to the endothermic release of DNA-hydrating ordered water molecules into the bulk solvent. Since the introduction of the $\mathrm{N}+$ modification compensated for the negative charge on the DNA backbone, the change in the entropy costs for N+ON/ DNA between $100 \mathrm{mM}$ and $25 \mathrm{mM} \mathrm{NaCl}$ solutions was less than that for the unmodified duplex $(\Delta(T \Delta S)=-74 \mathrm{~kJ} / \mathrm{mol}$ for $\mathrm{N}+\mathrm{ON} / \mathrm{DNA}$ versus $-95 \mathrm{~kJ} / \mathrm{mol}$ for the native DNA duplex, respectively). A similar trend was seen for the Ts-modified ONs
$(\Delta(T \Delta S)=-43 \mathrm{~kJ} / \mathrm{mol})$, but the change in $\Delta H$ between $25 \mathrm{mM}$ and $100 \mathrm{mM} \mathrm{NaCl}$ was the lowest for the duplexes with DNA $(\Delta \Delta H=28 \mathrm{~kJ} / \mathrm{mol})$. This indicates that the hydrophobicity of Ts results in less water molecules involved in the formation of hydrogen bonds with dsDNA. However, it does not improve the interaction between two DNA strands, possibly due to the large size of the Ts moiety.

For duplexes of the N+ and Ts-ONs formed with complementary RNA, both $\Delta H$ and $T \Delta S$ terms were more negative at the same salt concentration than those for the unmodified ON/RNA complex, which is the opposite to duplexes formed with DNA. This led to even larger enthalpy-entropy compensation at the medium salt concentration $(100 \mathrm{mM} \mathrm{NaCl})$. When the $\mathrm{NaCl}$ concentration decreased from $100 \mathrm{mM}$ to $25 \mathrm{mM}$, even though the reduction of entropy costs for the Ts-ON/RNA duplex was minimal for the RNA $(\Delta(T \Delta S)=-33 \mathrm{~kJ} / \mathrm{mol})$, the loss in $\Delta G$ for Ts-ON/RNA duplexes was larger than that of unmodified and $\mathrm{N}+\mathrm{ON} / \mathrm{RNA}$ duplexes $\left(\Delta \Delta G_{298}=0,6\right.$, and $20 \mathrm{~kJ} / \mathrm{mol}$ for unmodified DNA/RNA, N+ON/RNA, and Ts-ON/RNA, respectively). This resulted in an unstable Ts-ON/RNA duplex at $25 \mathrm{mM} \mathrm{NaCl}$. However, it should be noted that a significantly improved $\Delta H$ for Ts-ON/RNA duplex in comparison with the native $\mathrm{ON} / \mathrm{RNA}$ at $100 \mathrm{mM} \mathrm{NaCl}(\Delta H=-407 \mathrm{~kJ} / \mathrm{mol}$ versus $-306 \mathrm{~kJ} / \mathrm{mol}$, respectively) which is accountable for the more favourable $\Delta G_{298}$ and higher $T_{\mathrm{m}}$ value. 


\section{Evaluation of $\mathrm{N}^{+}$and Ts-modified ONs towards enzymatic digestion}

The nuclease resistance of the modified ONs was evaluated using snake venom phosphodiesterase (phosphodiesterase I, Sigma) and compared to the unmodified sequence ON1. Under the conditions used in this experiment, ON1 was completely degraded within 30 min (Figure 2). Both, $\mathrm{N}+$ and Ts-modified ONs showed an enhanced nuclease resistance when modifications were present at the 3'-end and /or in the middle of the sequence. A single $\mathrm{N}+$ or Ts modification at the 5 '-end of the $\mathrm{ON}$ did not provide protection against phosphodiesterase I. However, the resistance of the modified ONs towards phosphodiesterase increased with the number of modifications present. $\mathrm{N}+\mathrm{ONs}$, with the same number of modifications, showed a higher resistance to nuclease degradation than Ts-ONs. For example, $92.0 \pm 1.8 \%$ of $\mathbf{4 N}+\mathbf{O N} 7$ remained intact, whereas only $54 \pm 3 \%$ of $\mathbf{4 T s}-\mathbf{O N 1 3}$ was intact after 120 min of enzymatic digestion (Figure 2, see also Figure S17 in Supporting Information File 1). N+ONs possessing more than four modifications showed a full enzymatic resistance after $120 \mathrm{~min}$ [38].

\section{Cell-uptake study}

The cellular uptake of three modified ONs synthesised possessing four or five $\mathrm{N}+$ or four Ts modifications and a fluorescent label (6-FAM) at the 3'-end (Table 1) was tested. Asynchronously growing NIH3T3 mouse fibroblasts were incubated with the ONs for 12 hours, fixed in $4 \%$ paraformaldehyde before the cells were processed for fluorescent confocal microscopy.

Figure 3 shows that FAM-labelled Ts and N+-modified DNAs are concentrated in vesicles (punctate foci in the oligo/FAM panel) that accumulate around the edge of the nucleus. Interestingly, the Ts-modified oligo is also present in the nucleus as indicated by the colocalisation of the ON (Figure 3E) with the nuclear DNA (Figure 3D). The diffuse nuclear pattern of the Ts-modified ON suggests they can escape the endocytic vesicles and enter the nucleus via the nuclear pores. This is in contrast to the lack of colocalisation of the FAM signal with the nuclear DNA in the negative control (no oligo) and for the $\mathrm{N}+$-modified oligos (Figure 3B, H, and $\mathrm{K}$, respectively). Confocal microscope sections that dissect the nucleus were collected showing that the FAM-ON imaged were in the cytoplasm when localised adjacent to the nucleus and not on the cell surface. Staining of the cell membrane, along with the nuclear DNA, confirmed that the Ts-ON foci are present within the cytoplasm as shown in Figure 4.

\section{Discussion}

Chemical modification provides an effective and efficient way of obtaining therapeutic antigene/antisense agents based on the nucleic acid scaffold. To regulate transcription or translation, chemically modified ONs need to be able to enter the cell, resist nuclease degradation, not be toxic to the cell, and importantly, bind to the target DNA or RNA in a sequence-specific manner with high affinity [46]. The electrostatic repulsion between negatively charged phosphates is considered to be one of the factors that determines the thermodynamic stability of nucleic acid secondary structures. Neutral or positively charged oligonucleotide analogues should bind more tightly with complementary DNA or RNA. Several studies have focused on the introduction of positively charged groups to a nucleobase $[47,48]$, a sugar [49,50], or the DNA backbone [51-53] leading to the formation of more stable duplexes and triplexes [54]. The
A)

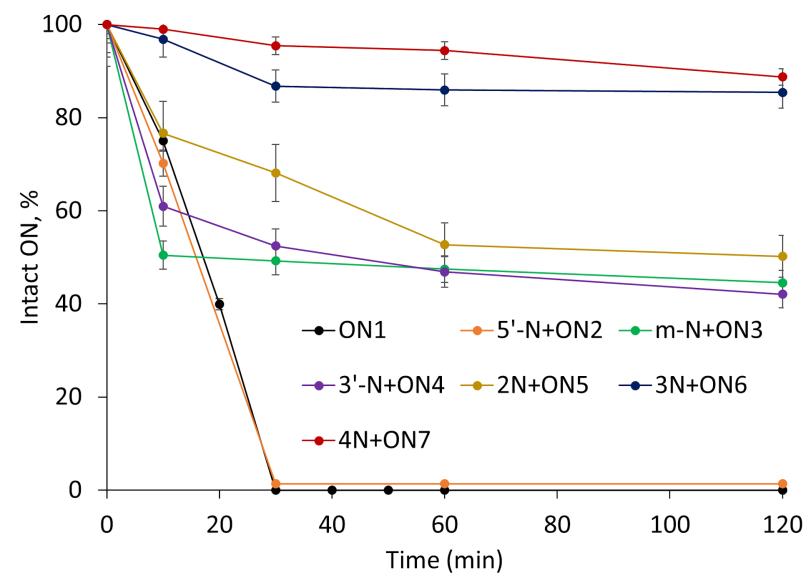

B)

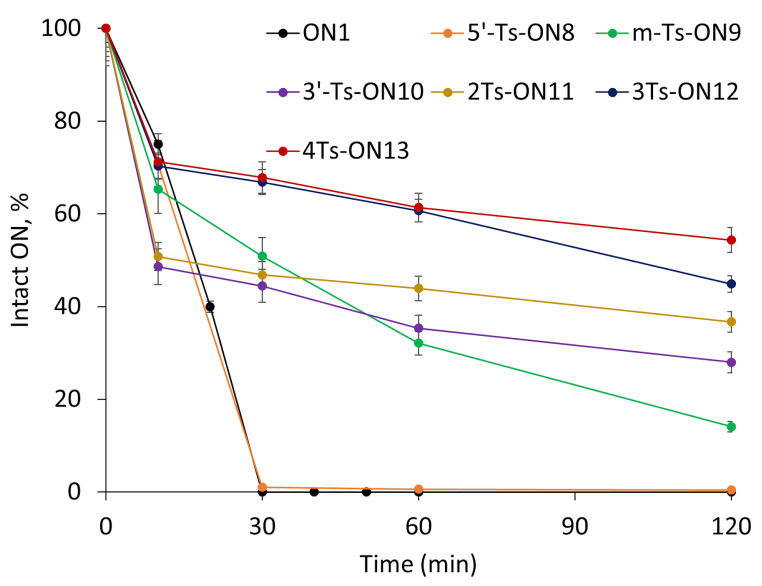




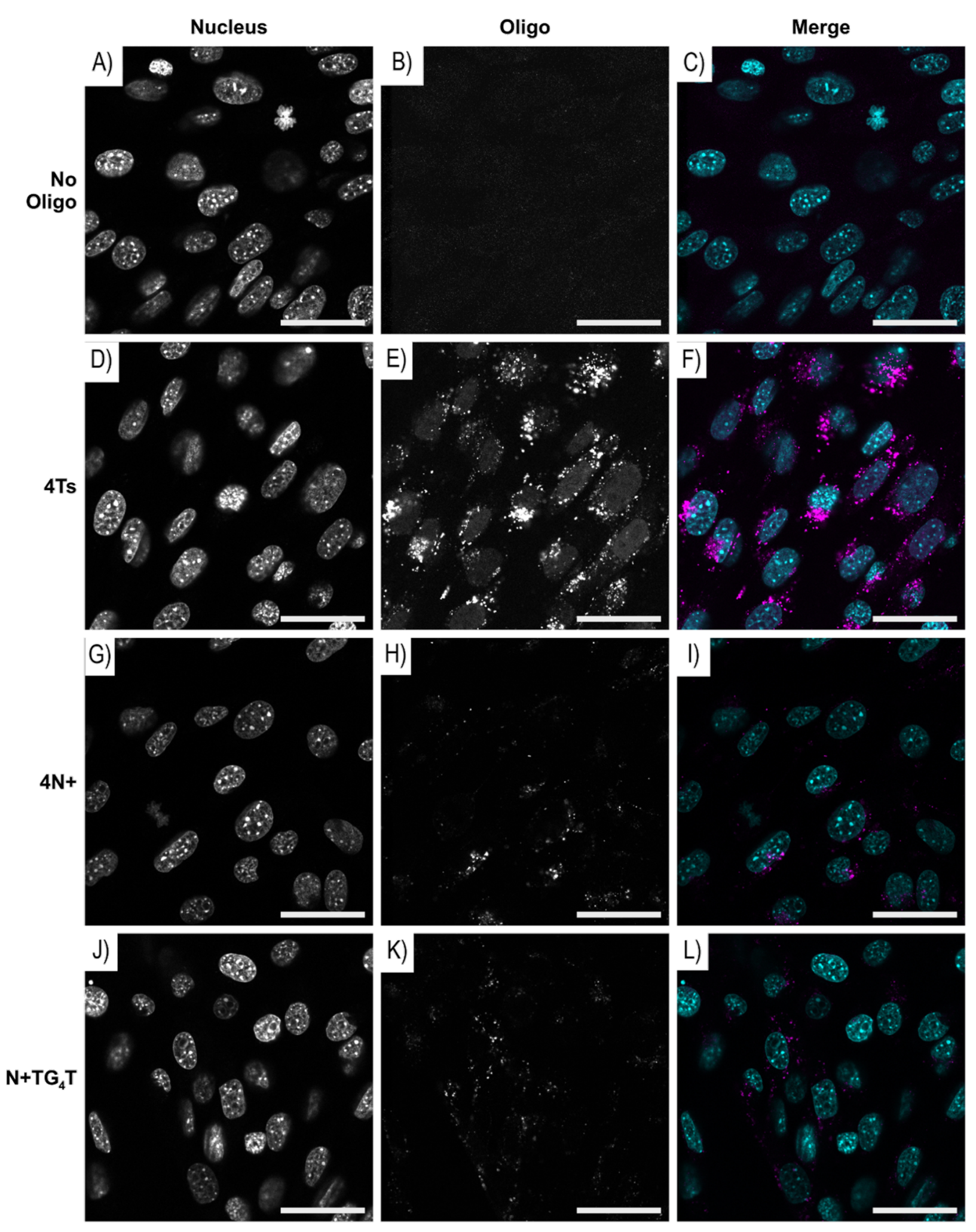

Figure 3: Representative images of mouse NIH 3T3 fibroblasts incubated with either (A-C) no oligo or $20 \mu \mathrm{M}$ of (D-F) 4Ts, (G-I) 4N+, and (J-L) $\mathrm{N}+\mathrm{TG}_{4} \mathrm{~T}$ FAM labelled ONs. Asynchronously growing NIH3T3 cells were incubated for 12 hours with $20 \mu \mathrm{M}$ of the stated FAM-labelled ONs or without ON, then fixed with $4 \%$ paraformaldehyde before staining with Hoechst 3342 to identify nuclear DNA. The images were collected with a Leica SP5 DM6000B scanning confocal microscope. Individual panels, nucleus/Hoechst 3342 and oligo/FAM are shown for each section, along with merge where pseudo-coloured panels are overlaid, nucleus (blue) and oligo (magenta). Scale bar: $40 \mu \mathrm{m}$. 


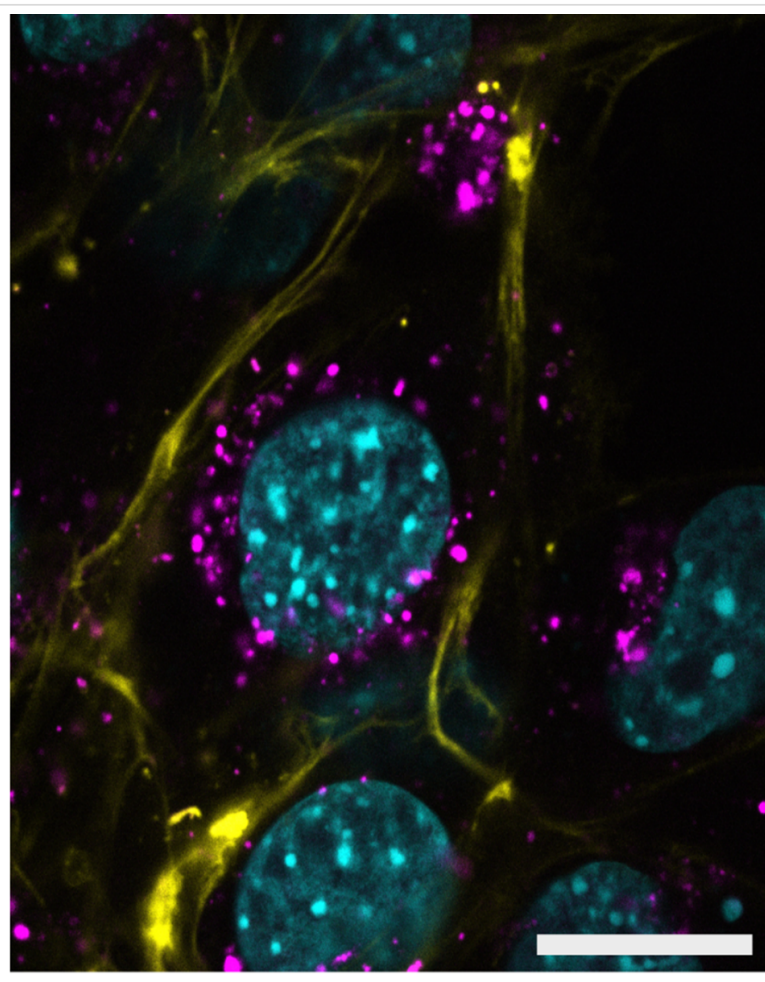

Figure 4: Representative confocal microscopy section showing the FAM vesicles inside the cell. Mouse NIH 3 T3 fibroblasts were incubated with $20 \mu \mathrm{M}$ of the FAM-labelled 4Ts-ON for 12 hours, then stained with CellBrite Fix 640 (Biotium) to identify the cell membrane before fixation with $4 \%$ paraformaldehyde. Nuclear DNA was then stained with Hoechst 3342 and images collected with a Leica SP5 DM6000B scanning confocal microscope. Overlaid pseudo-coloured panels of a section are shown: nuclear DNA (blue), 4Ts-FAM/ON (magenta), cell membrane (yellow). Scale bar: $20 \mu \mathrm{m}$.

introduction of sulfonamide RNA (SaRNA monomers) to replace the phosphodiester backbone led to charge-neutral sulfonamide antisense oligonucleotides (SaASOs), which resulted in a lower destabilisation (a more stable) DNA-RNA duplex compared to a DNA-DNA duplex [55]. In contrast, the incorporation of branched, charge-neutralising sleeve (BCNS) groups onto the DNA backbone led to self-neutralising ONs that did not induce a change of $T_{\mathrm{m}}$ when binding complementary DNA sequences [56], regardless of the number of BCNSs incorporated. This is in line with our results where increasing the number of $\mathrm{N}+$ or Ts modifications showed no benefit in $T_{\mathrm{m}}$ values of the antiparallel duplexes formed with complementary RNA or DNA.

In order to be compatible with standard automated solid-phase DNA or RNA synthesis, the introduction of SaRNA monomers into an RNA backbone involved a 14-step preparation of the phosphoramidite for the SaRNA-TT dinucleotide. Similarly, the incorporation of BCNS groups on a DNA backbone requires the synthesis of thymidine and 2'-OMe-uridine phosphoramidites bearing BCNS groups comprising nine and ten synthetic steps, respectively. In comparison, the synthesis of an $\mathrm{N}+$ monomer requires only four synthetic steps starting from commercially available 1,4-butane sultone that does not have any silica gel purification [38]. The incorporation of the $\mathrm{N}+$ modification onto DNA is performed during DNA synthesis instead of a standard oxidation step. Moreover, $\mathrm{N}+$ and Ts modifications can be introduced into any position in the sequence, which is not the case for SaRNA and BCNS nucleic acid analogues.

Unlike PNAs and some of BCNS groups, $\mathrm{N}+$ and Ts-modified ONs demonstrated excellent chemical stability and solubility in buffer solutions. The presence of the $\mathrm{N}+$ modification enhanced the stability of parallel triplexes at $\mathrm{pH}$ 5.0. The Ts modification also stabilises parallel triplexes at $\mathrm{pH} 5.0$, but the stability decreased with increasing number of Ts moieties incorporated. Apart from ONs with $\mathrm{N}+$ or Ts modifications in the middle of the sequence, both types of modified ONs hybridised with complementary RNA with a higher thermal stability than with DNA, suggesting that the $\mathrm{N}+$ and Ts modifications can be used in antisense strategies. This is in contrast with reports that ONs with Ts groups destablised the duplex formation with complementary RNA ( $\Delta T_{\mathrm{m}}=-1.6$ to $-1.2{ }^{\circ} \mathrm{C} /$ modification) [39], which suggests that the effect of the Ts modification on the $T_{\mathrm{m}}$ is dependent on the sequence.

The thermal stability of duplexes formed by N+ONs and their complementary DNA sequence was less dependent on the ionic strength, which was predicted for zwitterionic nucleotides that can bind to natural DNA at low ionic strength as well or better than natural DNA [57]. Similar results have been reported for ONs with BCNS groups: the $T_{\mathrm{m}}$ of 2'-OMe duplexes was increased with increasing numbers of BCNSs at low ionic strength (25 mM HEPES buffer, $\mathrm{pH}$ 7.3). When binding to complementary RNA sequences, such behaviour was not as noticeable. It has been reported in the past that $T_{\mathrm{m}}$ values for ON/RNA duplexes are less sensitive to changes in the ionic strength in comparison with ON/DNA duplexes [58]. The Ts modification stabilised the duplex formation with RNA at a salt concentration of $100 \mathrm{mM}$, but destabilised the RNA duplex at low salt concentration.

The thermodynamic analysis of the melting curves revealed that the $\mathrm{N}+$ modification stabilises the duplex with DNA because of a significantly reduced loss in entropy but stabilises the duplex formation with RNA because of the improved enthalpy at the same salt concentrations. A similar trend for $\Delta H$ and $T \Delta S$ is observed for the Ts modification compared to native DNA.

In line with the recent report [37], the loss of the thermodynamic stability at low salt concertations for the native DNA duplex was caused by the large entropic penalty that was not 
compensated by the improved enthalpy. For the native RNA duplex, entropic penalty and improved enthalpy cancelled each other out resulting in a similar thermodynamic stability in the presence of 25 and $100 \mathrm{mM} \mathrm{NaCl}$.

The polyelectrolyte ion condensation theory can be used to explain how an $\mathrm{N}+$ modification stabilises duplex formation: For natural DNA, the double-helical form has a higher charge density in comparison with the single-stranded form. During denaturation, a portion of the counterions bound to DNA are lost to the bulk solvent due to the reduction in charge density. For a DNA duplex with one zwitterionic strand, the charge density of duplex and single stranded states is balanced, and only a fraction of the counterions should be lost during denaturation. As a result, the thermal stability of zwitterionic N+ DNA duplexes was less dependent on the ionic strength $[57,59]$. This is in line with our thermodynamic analysis that the dsDNA having $\mathrm{N}+$ modifications showed less entropy costs when the ionic strength changed.

Native DNA and RNA sequences are highly susceptible to nuclease degradation within the cell. A modification on the phosphate group reduces the possibility of enzymatic digestion, which will be useful for cellular applications of $\mathrm{N}+$ and Ts-modified ONs. The introduction of even a single $\mathrm{N}+$ and $\mathrm{Ts}$ modification at the 3 '-end, but not at the 5'-end, leads to the resistance of the modified ONs to enzymatic digestion by snake venom phosphodiesterase I.

The FAM-labelled ONs were shown to enter cells without the use of a transfection reagent. After a 12 hour incubation, the Ts-ON was present in both the cytoplasm and nucleus. In comparison, there was less cellular uptake of $4 \mathrm{~N}+\{\mathrm{FAM}\} \mathrm{ON}$ and it was only present in the cytoplasm. These results indicate that ONs with phosphate modifications such as $\mathrm{N}+$ or Ts might be suitable tools for the application of DNA and RNA vaccines [60], for the treatment of cancer [61], infectious diseases [62], and neurological disorders [63].

\section{Conclusion}

ONs possessing $\mathrm{N}+$ and Ts modifications have good aqueous solubility and chemical stability, which allowed the assessment of these modifications in the context of DNA triplexes and duplexes. The presence of $\mathrm{N}+$ or Ts modifications on the internucleotidic phosphates enhanced the binding affinity of the ONs for complementary RNA and increased their resistance to digestion by phosphodiesterase I. Fluorescently labelled Ts-ONs penetrate the cell and enter the nucleus, while $\mathrm{N}+\mathrm{ONs}$ remain trapped in vesicles in the cytoplasm. These properties make the $\mathrm{N}+$ and Ts-modified ONs promising candidates for cell-based applications.

\section{Supporting Information}

\section{Supporting Information File 1}

Experimental part.

[https://www.beilstein-journals.org/bjoc/content/

supplementary/1860-5397-17-65-S1.pdf]

\section{Acknowledgements}

Manawatu Microscopy and Imaging Centre, NMR and mass spectrometry facilities at Massey University, and the assistance of Mr. Raoul Solomon, Dr. Patrick J. B. Edwards, and Mr. David Lun are gratefully acknowledged. We thank Dr. Maksim V. Kvach for valuable discussions and suggestions. We also thank Mr. Raoul Solomon for assistance in the preparation of Figure 3 and Figure 4.

\section{Funding}

V.V.F. and Y.S. are grateful for the financial support provided by the School of Fundamental Sciences (Massey University) and Cancer Society of New Zealand (grant No 15/07). TKH and MB thank the Health Research Council of New Zealand (grant 19/771).

\section{ORCID ${ }^{\circledR}$ iDs}

Yongdong Su - https://orcid.org/0000-0002-2092-8872 Maitsetseg Bayarjargal - https://orcid.org/0000-0001-9235-9149 Tracy K. Hale - https://orcid.org/0000-0002-9483-4588 Vyacheslav V. Filichev - https://orcid.org/0000-0002-7383-3025

\section{Preprint}

A non-peer-reviewed version of this article has been previously published as a preprint: https://doi.org/10.3762/bxiv.2020.138.v1

\section{References}

1. Muangkaew, P.; Vilaivan, T. Bioorg. Med. Chem. Lett. 2020, 30, 127064. doi:10.1016/j.bmcl.2020.127064

2. Xiao, Y.; Sheng, Y.; Zhou, J.; Chen, M.; Wen, W.; Zhang, X.; Wang, S. Analyst 2017, 142, 2617-2623. doi:10.1039/c7an00553a

3. Qadir, M. I.; Bukhat, S.; Rasul, S.; Manzoor, H.; Manzoor, M. J. Cell. Biochem. 2020, 121, 898-929. doi:10.1002/jcb.29364

4. Bennett, C. F.; Swayze, E. E. Annu. Rev. Pharmacol. Toxicol. 2010, 50, 259-293. doi:10.1146/annurev.pharmtox.010909.105654

5. Uil, T. G.; Haisma, H. J.; Rots, M. G. Nucleic Acids Res. 2003, 31, 6064-6078. doi:10.1093/nar/gkg815

6. Wu, J.; Kandavelou, K.; Chandrasegaran, S. Cell. Mol. Life Sci. 2007, 64, 2933-2944. doi:10.1007/s00018-007-7206-8

7. Boch, J. Nat. Biotechnol. 2011, 29, 135-136. doi:10.1038/nbt.1767

8. Deltcheva, E.; Chylinski, K.; Sharma, C. M.; Gonzales, K.; Chao, Y.; Pirzada, Z. A.; Eckert, M. R.; Vogel, J.; Charpentier, E. Nature 2011, 471, 602-607. doi:10.1038/nature09886 
9. Jinek, M.; Chylinski, K.; Fonfara, I.; Hauer, M.; Doudna, J. A.; Charpentier, E. Science 2012, 337, 816-821.

doi:10.1126/science.1225829

10. Hsu, P. D.; Lander, E. S.; Zhang, F. Cell 2014, 157, 1262-1278. doi:10.1016/j.cell.2014.05.010

11. Hsu, P. D.; Scott, D. A.; Weinstein, J. A.; Ran, F. A.; Konermann, S.; Agarwala, V.; Li, Y.; Fine, E. J.; Wu, X.; Shalem, O.; Cradick, T. J.; Marraffini, L. A.; Bao, G.; Zhang, F. Nat. Biotechnol. 2013, 31 , 827-832. doi:10.1038/nbt.2647

12. Jensen, E. D.; Ferreira, R.; Jakočiūnas, T.; Arsovska, D.; Zhang, J.; Ding, L.; Smith, J. D.; David, F.; Nielsen, J.; Jensen, M. K.; Keasling, J. D. Microb. Cell Fact. 2017, 16, 46. doi:10.1186/s12934-017-0664-2

13. Sundaresan, R.; Parameshwaran, H. P.; Yogesha, S. D.; Keilbarth, M. W.; Rajan, R. Cell Rep. 2017, 21, 3728-3739. doi:10.1016/j.celrep.2017.11.100

14. Lee, J. K.; Jeong, E.; Lee, J.; Jung, M.; Shin, E.; Kim, Y.-h.; Lee, K.; Jung, I.; Kim, D.; Kim, S.; Kim, J.-S. Nat. Commun. 2018, 9, 3048. doi:10.1038/s41467-018-05477-x

15. Moser, H. E.; Dervan, P. B. Science 1987, 238, 645-650. doi:10.1126/science.3118463

16. Wu, Q.; Gaddis, S. S.; MacLeod, M. C.; Walborg, E. F.; Thames, H. D.; DiGiovanni, J.; Vasquez, K. M. Mol. Carcinog. 2007, 46, 15-23. doi:10.1002/mc.20261

17. Hoogsteen, K. Acta Crystallogr. 1963, 16, 907-916. doi:10.1107/s0365110x63002437

18. Jain, M. L.; Bruice, P. Y.; Szabó, I. E.; Bruice, T. C. Chem. Rev. 2012, 112, 1284-1309. doi:10.1021/cr1004265

19. Crooke, S. T.; Liang, X.-h.; Baker, B. F.; Crooke, R. M. J. Biol. Chem. 2021, 100416. doi:10.1016/j.jbc.2021.100416

20. Hansen, M. E.; Bentin, T.; Nielsen, P. E. Nucleic Acids Res. 2009, 37, 4498-4507. doi:10.1093/nar/gkp437

21. Obika, S.; Nanbu, D.; Hari, Y.; Morio, K.-i.; In, Y.; Ishida, T.; Imanishi, T. Tetrahedron Lett. 1997, 38, 8735-8738. doi:10.1016/s0040-4039(97)10322-7

22. Koshkin, A. A.; Singh, S. K.; Nielsen, P.; Rajwanshi, V. K.; Kumar, R.; Meldgaard, M.; Olsen, C. E.; Wengel, J. Tetrahedron 1998, 54, 3607-3630. doi:10.1016/s0040-4020(98)00094-5

23. Padmapriya, A. A.; Tang, J. Y.; Agrawal, S. Antisense Res. Dev. 1994, 4, 185-199. doi:10.1089/ard.1994.4.185

24. Eckstein, F. Antisense Nucleic Acid Drug Dev. 2000, 10, 117-121. doi:10.1089/oli.1.2000.10.117

25. Lohse, J.; Dahl, O.; Nielsen, P. E. Proc. Natl. Acad. Sci. U. S. A. 1999, 96, 11804-11808. doi:10.1073/pnas.96.21.11804

26. Wan, W. B.; Seth, P. P. J. Med. Chem. 2016, 59, 9645-9667. doi:10.1021/acs.jmedchem.6b00551

27. Koshkin, A. A.; Nielsen, P.; Meldgaard, M.; Rajwanshi, V. K.; Singh, S. K.; Wengel, J. J. Am. Chem. Soc. 1998, 120, 13252-13253. doi:10.1021/ja9822862

28. Singh, S. K.; Koshkin, A. A.; Wengel, J.; Nielsen, P. Chem. Commun. 1998, 455-456. doi:10.1039/a708608c

29. Seth, P. P.; Siwkowski, A.; Allerson, C. R.; Vasquez, G.; Lee, S.; Prakash, T. P.; Wancewicz, E. V.; Witchell, D.; Swayze, E. E. J. Med. Chem. 2009, 52, 10-13. doi:10.1021/jm801294h

30. Swayze, E. E.; Siwkowski, A. M.; Wancewicz, E. V.; Migawa, M. T.; Wyrzykiewicz, T. K.; Hung, G.; Monia, B. P.; Bennett, C. F. Nucleic Acids Res. 2007, 35, 687-700. doi:10.1093/nar/gkl1071

31. Nakamura, A.; Ali, S. A.; Kapoor, M. Bone 2020, 138, 115461. doi:10.1016/j.bone.2020.115461
32. De Costa, N. T. S.; Heemstra, J. M. PLoS One 2013, 8, e58670. doi:10.1371/journal.pone.0058670

33. Miller, P. S.; McParland, K. B.; Jayaraman, K.; Tso, P. O. P. Biochemistry 1981, 20, 1874-1880. doi:10.1021/bi00510a024

34. Shoji, Y.; Akhtar, S.; Periasamy, A.; Herman, B.; Juliano, R. L. Nucleic Acids Res. 1991, 19, 5543-5550. doi:10.1093/nar/19.20.5543

35. Nagahama, K.; Veedu, R. N.; Wengel, J. Bioorg. Med. Chem. Lett. 2009, 19, 2707-2709. doi:10.1016/j.bmcl.2009.03.116

36. Saccà, B.; Lacroix, L.; Mergny, J.-L. Nucleic Acids Res. 2005, 33, 1182-1192. doi:10.1093/nar/gki257

37. Kuo, T.-C.; Wu, M.-W.; Lin, W.-C.; Matulis, D.; Yang, Y.-S.; Li, S.-Y.; Chen, W.-Y. J. Taiwan Inst. Chem. Eng. 2020, 110, 1-7. doi:10.1016/j.jtice.2020.02.023

38. Su, Y.; Edwards, P. J. B.; Stetsenko, D. A.; Filichev, V. V. ChemBioChem 2020, 21, 2455-2466. doi:10.1002/cbic.202000110

39. Prokhorova, D. V.; Chelobanov, B. P.; Burakova, E. A.; Fokina, A. A.; Stetsenko, D. A. Russ. J. Bioorg. Chem. 2017, 43, 38-42. doi:10.1134/s1068162017010071

40. Felsenfeld, G.; Miles, H. T. Annu. Rev. Biochem. 1967, 36, 407-448. doi:10.1146/annurev.bi.36.070167.002203

41. Doluca, O.; Withers, J. M.; Filichev, V. V. Chem. Rev. 2013, 113, 3044-3083. doi:10.1021/cr300225q

42. El Hassan, M. A.; Calladine, C. R. J. Mol. Biol. 1996, 259, 95-103. doi:10.1006/jmbi.1996.0304

43. Kotin, L. J. Mol. Biol. 1963, 7, 309-311. doi:10.1016/s0022-2836(63)80009-1

44. Xia, T.; SantaLucia, J., Jr.; Burkard, M. E.; Kierzek, R.; Schroeder, S. J.; Jiao, X.; Cox, C.; Turner, D. H. Biochemistry 1998, 37, 14719-14735. doi:10.1021/bi9809425

45. Mergny, J.-L.; Lacroix, L. Oligonucleotides 2003, 13, 515-537. doi:10.1089/154545703322860825

46. Rayburn, E. R.; Zhang, R. Drug Discovery Today 2008, 13, 513-521. doi:10.1016/j.drudis.2008.03.014

47. Robles, J.; Grandas, A.; Pedroso, E. Tetrahedron 2001, 57, 179-194. doi:10.1016/s0040-4020(00)00991-1

48. Roig, V.; Asseline, U. J. Am. Chem. Soc. 2003, 125, 4416-4417. doi:10.1021/ja029467v

49. Kanazaki, M.; Ueno, Y.; Shuto, S.; Matsuda, A. J. Am. Chem. Soc. 2000, 122, 2422-2432. doi:10.1021/ja9934706

50. Puri, N.; Majumdar, A.; Cuenoud, B.; Natt, F.; Martin, P.; Boyd, A.; Miller, P. S.; Seidman, M. M. Biochemistry 2002, 41, 7716-7724. doi:10.1021/bi025734y

51. Bailey, P.; Sartorelli, V.; Hamamori, Y.; Muscat, G. E. O. Nucleic Acids Res. 1998, 26, 5501-5510. doi:10.1093/nar/26.23.5501

52. Michel, T.; Debart, F.; Vasseur, J.-J. Tetrahedron Lett. 2003, 44, 6579-6582. doi:10.1016/s0040-4039(03)01694-0

53. Vasquez, K. M.; Dagle, J. M.; Weeks, D. L.; Glazer, P. M. J. Biol. Chem. 2001, 276, 38536-38541. doi:10.1074/jbc.m101797200

54. Fox, K. R. Curr. Med. Chem. 2003, 7, 17-37. doi:10.2174/0929867003375506

55. Korotkovs, V.; Reichenbach, L. F.; Pescheteau, C.; Burley, G. A.; Liskamp, R. M. J. J. Org. Chem. 2019, 84, 10635-10648. doi:10.1021/acs.joc.9b00941

56. Yanachkov, I.; Zavizion, B.; Metelev, V.; Stevens, L. J.; Tabatadze, Y.; Yanachkova, M.; Wright, G.; Krichevsky, A. M.; Tabatadze, D. R. Org. Biomol. Chem. 2017, 15, 1363-1380. doi:10.1039/c6ob02576e

57. Hashimoto, H.; Nelson, M. G.; Switzer, C. J. Am. Chem. Soc. 1993, 115, 7128-7134. doi:10.1021/ja00069a009

58. Bentley, J.; Brazier, J. A.; Fisher, J.; Cosstick, R. Org. Biomol. Chem. 2007, 5, 3698-3702. doi:10.1039/b713292a 
59. Tomac, S.; Sarkar, M.; Ratilainen, T.; Wittung, P.; Nielsen, P. E.; Nordén, B.; Gräslund, A. J. Am. Chem. Soc. 1996, 118, 5544-5552. doi:10.1021/ja960495।

60. Leitner, W. W.; Ying, H.; Restifo, N. P. Vaccine 1999, 18, 765-777. doi:10.1016/s0264-410x(99)00271-6

61. Lopes, A.; Vandermeulen, G.; Préat, V. J. Exp. Clin. Cancer Res. 2019, 38, 146. doi:10.1186/s13046-019-1154-7

62. Rezaei, T.; Khalili, S.; Baradaran, B.; Mosafer, J.; Rezaei, S.; Mokhtarzadeh, A.; de la Guardia, M. J. Controlled Release 2019, 316, 116-137. doi:10.1016/j.jconrel.2019.10.045

63. Petrushina, I.; Hovakimyan, A.; Harahap-Carrillo, I. S.; Davtyan, H.; Antonyan, T.; Chailyan, G.; Kazarian, K.; Antonenko, M.; Jullienne, A.; Hamer, M. M.; Obenaus, A.; King, O.; Zagorski, K.; Blurton-Jones, M.; Cribbs, D. H.; Lander, H.; Ghochikyan, A.; Agadjanyan, M. G. Neurobiol. Dis. 2020, 139, 104823. doi:10.1016/j.nbd.2020.104823

\section{License and Terms}

This is an Open Access article under the terms of the Creative Commons Attribution License

(https://creativecommons.org/licenses/by/4.0). Please note that the reuse, redistribution and reproduction in particular requires that the author(s) and source are credited and that individual graphics may be subject to special legal provisions.

The license is subject to the Beilstein Journal of Organic Chemistry terms and conditions: (https://www.beilstein-journals.org/bjoc/terms)

The definitive version of this article is the electronic one which can be found at: https://doi.org/10.3762/bjoc.17.65 